\title{
HYDROGEOPHYSICAL DELINEATION OF PROLIFIC GROUNDWATER AQUIFER AROUND STUDENTS' HOSTELS IN FUPRE CAMPUS, NIGERIA
}

\author{
Alaminiokuma G.I.* and Omigie J.I. \\ Department of Earth Sciences, Federal University of Petroleum Resources Effurun, P.M.B. 1221, Effurun, Nigeria \\ "Corresponding Author E-mail: alaminiokuma.godswill@fupre.edu.ng
}

This is an open access article distributed under the Creative Commons Attribution License, which permits unrestricted use, distribution, and reproduction in any medium, provided the original work is properly cited.

\section{ARTICLE DETAILS}

\section{Article History:}

Received 08 March 2020 Accepted 10 April 2020

Available online 24 April 2020

\begin{abstract}
Electrical resistivity survey was conducted around Students' Hostels in FUPRE to delineate prolific aquifer for potable water to serve the teeming population of staff and students. Five vertical electrical soundings (VES) using Schlumberger electrode configuration with a maximum current electrode spread of $300 \mathrm{~m}$ were employed for data acquisition. WINRESIST software was employed to execute the iteration and inversion processes of computing resistivities, depths and thicknesses of the various layers and the curve types. Results indicate that the area is characterized by 4 distinct geoelectric layers inferred differently at the VES locations. Two potential groundwater aquifer zones are delineated. The unconfined shallow aquifer zones found at VES $1,3,4$ and 5 locations have shallow overburden depth ranging between $3.7-19.3 \mathrm{~m}$ and coarse-grained sand columns with thicknesses ranging between $2.8-17.7 \mathrm{~m}$ while the confined deep aquifer zone found at VES 2 location coincides with deep overburden layer at a depth of $42.6 \mathrm{~m}$ and coarse-grained sand column with appreciable thickness of $19.1 \mathrm{~m}$. These results suggest that boreholes for sustainable groundwater supply around the Students' Hostels should be sited at VES 2 location and screened at a depth $\geq 40.0 \mathrm{~m}$. However, aquifers at VES $1,3,4$ and 5 have potentials for groundwater but are vulnerable to contamination. It is recommenced that electrical resistivity and hydrogeological surveys should be conducted at different locations in FUPRE, before any borehole(s) are drilled, to delineate the appropriate aquifer for potable groundwater supply and to avoid possible contamination.
\end{abstract}

\section{KEYWORDS}

Vertical electrical sounding, aquifer, coarse-grained sand, groundwater, students' hostels, FUPRE campus.

\section{INTRODUCTION}

The rapid expansion in infrastructure and increase in population of staff and students witnessed by the Federal University of Petroleum Resources Effurun (FUPRE) and its proximity to surrounding communities such as Ugbomro, Iteregbi, Ebrumede, Okuatata, Okuokoko, Okorikpere and Agbarho where most staff and students reside have led to the growing high demands for potable water to serve the teeming population. Hence, the aim of this research is to delineate prolific groundwater aquifer with the objectives of determining the appropriate lithology for quality groundwater without mineralization and contamination, depth to the prolific aquifer and thickness to provide the maximum yield at all seasons of the year to meet this growing demands for potable water in the absence of public water utility system.

The water table regime in FUPRE Campus is very shallow as it is located within the relatively low terrain with porous and permeable sand that support groundwater percolation and retention. Most groundwater boreholes in this vicinity are bottomed at shallow depth (less than $40 \mathrm{~m}$ deep) and assumed to be very suitable for domestic and industrial uses but the mineralization level and dissolved salts reduce the quality as observed by Amadi, 2009 and Akpoborie, et. al. 2014. The availability of potable water basically depends on the soil composition, depth and thickness of aquifer and environmental factors such as content of dissolved salts, mineralization of rocks, among others. These factors control the groundwater potential and quality in any area and electrical resistivity survey, which involves introducing electrical current into the ground by electrodes and measuring the potential differences between layers at certain depths in the ground, has over time proven to be one of the easiest methods of determining the factors above for cheap access to good quality groundwater in aquifers. This is because the instrumentation and field logistics are easy to implement and data analysis is less tedious and economical to handle. Vertical electrical sounding (VES) is an electrical resistivity method for measuring vertical variations of electrical resistance in the ground is employed in this study.

Vertical electrical sounding (VES) has been recognized to be more suitable for hydrogeological surveys in sedimentary basin as shown by several researchers among others: Alaminiokuma and Chaanda, 2020 studied the groundwater potential of Mando, Kaduna, Crystalline Basement Complex, Nigeria using VES. The results show that the area is characterized by four to five geoelectric subsurface layers inferred differently at the VES traverses. An unconfined shallow aquifer zone was delineated. The potential groundwater aquifer zone found at all the VES locations has shallow overburden depth ranging between $7.1-10.9 \mathrm{~m}$ with coarsegrained sand columns having thicknesses ranging between $6.0-9.6 \mathrm{~m}$ suggesting that groundwater occurrence in Mando lies within the weathered overburden (WO) composed of coarse-grained sands which forms a level below the loose clayey laterite. Mgbolu et al., 2019 studied the groundwater potential, aquifer hydraulic characterization and 
vulnerability using VES in parts of Ndokwa, Niger Delta Basin, Nigeria. Results revealed five to six geo-electric layers/units across the study area. The subsurface lithology is predominantly sandstone intercalated, in some cases, with clay, sandy clay, and clayey sand. The average depth to aquifer as $71.91 \mathrm{~m}(10.33-173.97 \mathrm{~m})$; average aquifer thickness as $42.52 \mathrm{~m}$ (4.7$149.7 \mathrm{~m}$ ) and average aquifer resistivity value as $1289 \Omega \mathrm{m}(470.84-$ $2697.7 \Omega \mathrm{m}$ ). Average overburden thickness was estimated to be $28.53 \mathrm{~m}$ (4.28-62.44 m). Aquifer characteristics derived from the VES results gave average calculated aquifer transmissivity value as $1162.31 \mathrm{~m}^{2} /$ day (129.54-4181.31 $\mathrm{m}^{2} /$ day), and average calculated aquifer hydraulic conductivity as $27.28 \mathrm{~m} /$ day $(25.69-28.92 \mathrm{~m} /$ day $)$. Longitudinal conductance values range of $0.006-0.137$ were recorded from geo-electric field survey data in the area, indicating dominance of sand and sparse distribution of clay; and suggesting that the Aquifer Protective Capacity APC of the overburden above the aquifers in the study area is mostly poor to weak and prone to contamination from infiltration. Nwokocha et al., 2018 delineated aquifer in Omuma Local Government Area of Rivers State, Nigeria using VES. Results show that the resistivity range of the area lies between 25 and $7356.5 \Omega \mathrm{m}$ and a maximum depth of $70 \mathrm{~m}$ was penetrated. The quantitative and qualitative analysis delineates 4 to 5 distinct subsurface geo-electric layers and total of six different geo-electric curve types were obtained; AKQ, KQQ, AK, HQ, KHK, and HK. The aquifer thickness and iso-Resistivity maps delineated the area of study into grade I, grade II and grade III groundwater potential zones based on the aquifer thickness and resistivity values derived from the survey. The entire southern region and few parts of the west show good prospect of underground water with aquifer thickness of $56 \mathrm{~m}$ and above. IserhienEmekeme et. al., 2017 identified lithology and underground water conditions of Jeddo using geophysical and geochemical methods. Results of the resistivity sounding revealed that the formation is made up of clay, clayey sand, and fine to coarse-grained sand. The mean depth of the aquifer was obtained as $12.7 \mathrm{~m}$ while the aquifer resistivity ranged from 161 to $1728 \Omega \mathrm{m}$. The mean value of transmissivity obtained for the aquifer is $169 \mathrm{~m}^{2}$ day $^{-1}$ while analysis of the transmissivity revealed that about $6 \%$ of the study area has greatest potential for a productive aquifer. The study also revealed that the underground water flows in the northeastsouthwest direction.

Consequently, this research will serve as a model for the delineation of prolific aquifer suitable for the location of groundwater boreholes to serve as sources of potable water for the University Community and its environs. It is significant for the measurement of resistivities, thicknesses, depths and lithological structure of the study area.

\section{LOCATION, GEOGRAPHY, GEOLOGY AND HDROGEOLOGY OF THE STUDY AREA}

2.1 Location

The study area is located around the Students' Hostels within the campus of Federal university of Petroleum Resources Effurun, Nigeria (Figure 1).

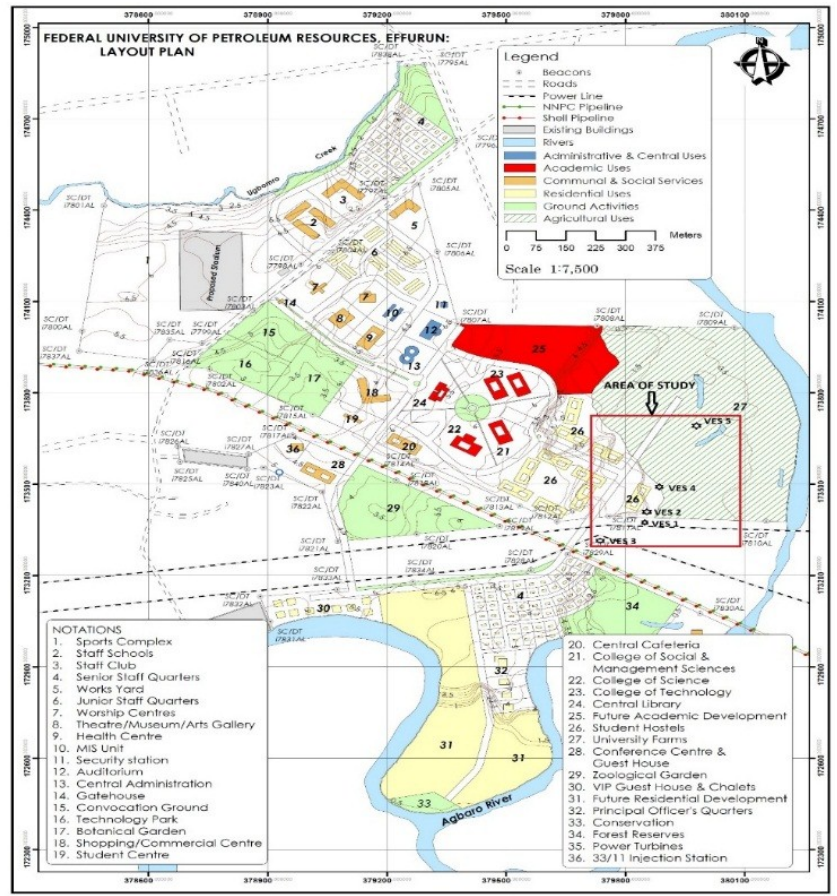

\subsection{Geography}

FUPRE is located between Ugbomro and Iteregbi Communities in Uvwie local Government Area of Delta State. These communities are surrounded by Okuatata, Okuokoko, Okorikpere and Agbarho communities. The area is a lowland with elevation not greater than $15 \mathrm{~m}$ above sea level. It is a relatively flat terrain and the area is drained by the Agbarho and Ugbomro Rivers.

The area is a hot/wet equatorial climate region made of two main seasons the wet and dry seasons. The climate is tropical equatorial type with mean annual rainfall greater than $300 \mathrm{~m}$ and mean temperature of about $28^{\circ} \mathrm{C}$ (Iloeje, 1981). The wet season begins from April and ends in September while dry season begins from October and ends in March. The study area has a direct recharge from rainfall, the rate of infiltration and percolation is very high. The area belongs to the freshwater vegetation belt of rainforest and swamp forest which is thickly vegetated with grass, trees and creeping plants.

\subsection{Geology}

The area of study is located within the Niger Delta which is the largest Basin in West Africa and the most prolific delta in Africa. The Niger Delta is situated on the continental margin of the Gulf of Guinea in equatorial West Africa between latitude $4^{\circ} \mathrm{N}$ to $7^{\circ} \mathrm{N}$ and longitude $5^{\circ} \mathrm{E}$ to $8^{\circ} \mathrm{E}$ covering an area of about $108900 \mathrm{~km}^{2}$ (Whiteman, 1982). It extends from the Calabar flank and the Abakaliki Trough in eastern Nigeria to the Benin flank in the west and it opens to the Atlantic Ocean in the south. The development of the Niger Delta resulted from the formation of the Benue trough as a failed arm of a triple junction associated with the separation of the Africa and South American Plates and subsequent opening of the South Atlantic (Whiteman, 1982).

The Benue-Abakaliki trough was filled with sediments during the early Cretaceous time, which later underwent folding, faulting and uplift with subsidence of the adjacent Anambra basin to the west and Afikpo syncline to the east during the Santonian. The Niger Delta consists of three diachronous units, namely from bottom, Akata, Agbada and Benin Formations (Weber and Daukoru, 1975).

\subsection{Hydrogeology}

The study area is underlain by the Quaternary Warri deltaic sand (EtuEfeotor and Akpokodje, 1990). The sediment overlies the Coastal Plain sand. It is characterized by yellowish colour and consists of silt, sand and clay. The sands are generally loose, porous, poorly sorted and lateritic. Small proportions of gravels and limited number of thin clay horizons are sometimes present at greater depths (Avbovbo, 1978). According to Amadi (2009), two main aquiferous units have been identified in the study area. The shallowest aquifer of $2-5 \mathrm{~m}$ depth occurs within the unconfined superficial alluvium comprising of sandy/silty layers. Hand dug wells exploit water from this aquifer. Deeper, confined and prolific aquifers are encountered at about $55 \mathrm{rn}$.

This aquifer consists of medium-to-coarse grained sand and gravel Industrial and public boreholes derive their source from the second aquifer. Water level in this area fluctuates in response to climatic conditions, Average water level in the dry season is $3.0 \mathrm{~m}$ while it rises to the ground level during the rainy season (Amadi, 2009).

\section{METHODOLOGY}

\subsection{Field Data Acquisition}

Ohmega 1000 Resistivity Meter was employed in acquiring the Vertical Electrical Sounding data along 5 traverses. The Schlumberger configuration (Figure 2) with a maximum current electrodes separation of $300 \mathrm{~m}$ was employed. Two current electrodes were placed linearly at the same mid-point with two potential electrodes but at different distances from one another. The current electrodes were placed at equal distances, $\boldsymbol{s}$ from the mid-point of the array while the potential electrodes were similarly placed at equal distances but at a distance, $a / 2<\boldsymbol{s}$. Different spreads of current electrodes, AB were achieved, thereby resulting in different probe depths (Table 1). The measurements were repeated 4 times at each point and the average was recorded to ensure accuracy of the results.

Figure 1: Map of FUPRE campus showing the study area 


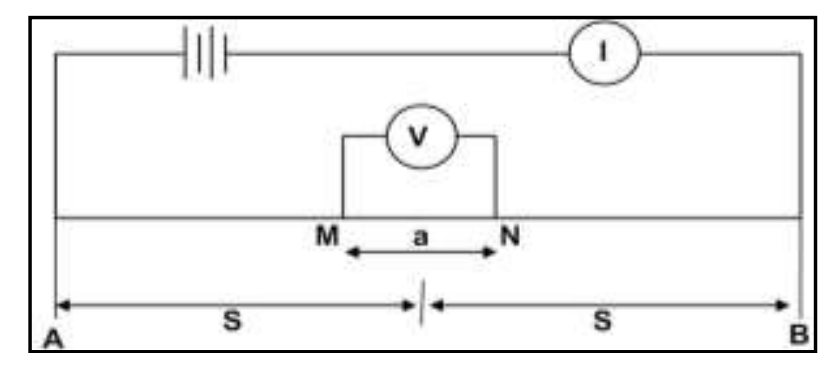

Figure 2: Schlumberger array for data acquisition

\subsection{Computation of Soil Apparent Resistivity, $\rho_{a}$}

Apparent resistivities were obtained from field resistance values using the equation:

$$
\rho_{a}=\frac{2 \pi R}{\left[\frac{1}{A M}-\frac{1}{A N}-\frac{1}{B M}+\frac{1}{B N}\right]}
$$

Where $\rho_{\mathrm{a}}$ is apparent resistivity, $\mathrm{R}$ is the measured resistance, $\mathrm{AB}=$

Distance between current electrodes, MN=Distance between potential electrodes and $\left[\frac{1}{A M}-\frac{1}{A N}-\frac{1}{B M}+\frac{1}{B N}\right]$ is the geometric factor, $\mathrm{K}$.

\section{DATA INTERPRETATION}

The apparent resistivity, $\rho_{\mathrm{a}}$ values were plotted against half current electrode spread, $\mathrm{AB} / 2$ employing WINRESIST software. For each VES station, the iteration process was conducted until the root mean square (RMS) error of $\leq 3.7 \%$ was obtained. The resistivities, thicknesses and depth of the various layers were computed and the curve types were determined.

\section{RESULTS AND DISCUSSION}

\subsection{Results}

Table 1 shows the VES data acquired around the students' hostels while figures $3-7$ show the geoelectric sections for the five VES stations. Generally, the KQ type curve except VES 1 with AQ type curve were observed in the study area.

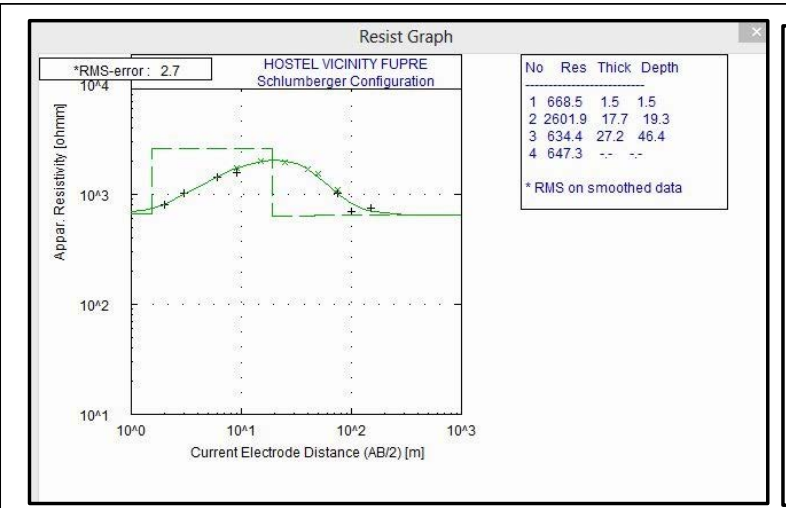

Figure 3: Geoelectric section for VES 1

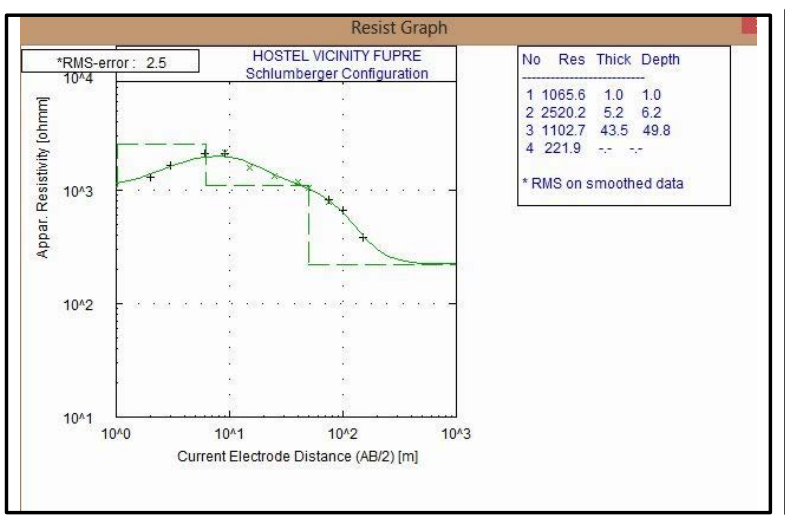

Figure 5: Geoelectric section for VES 3

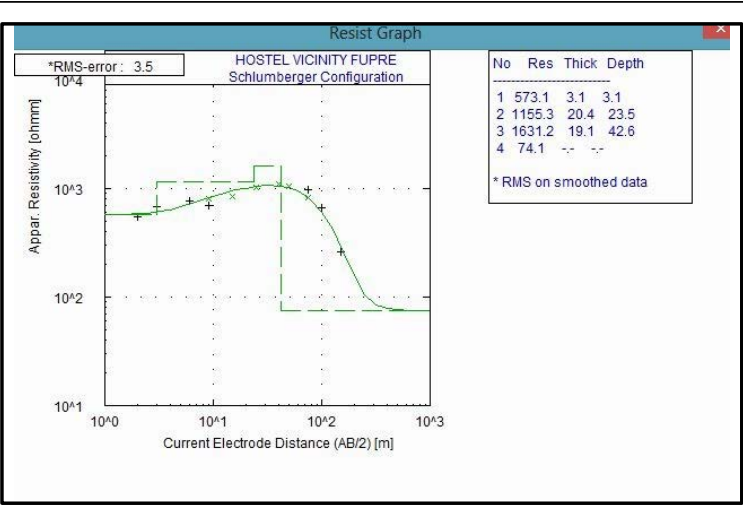

Figure 4: Geoelectric section for VES 2

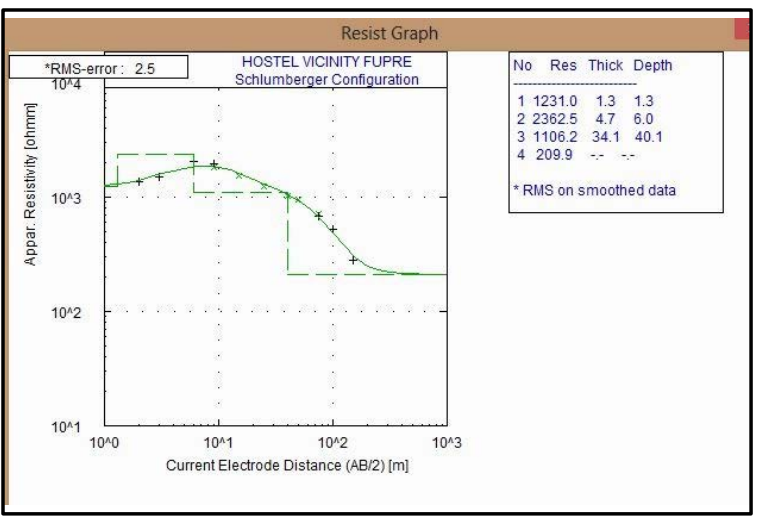

Figure 6: Geoelectric section for VES 4

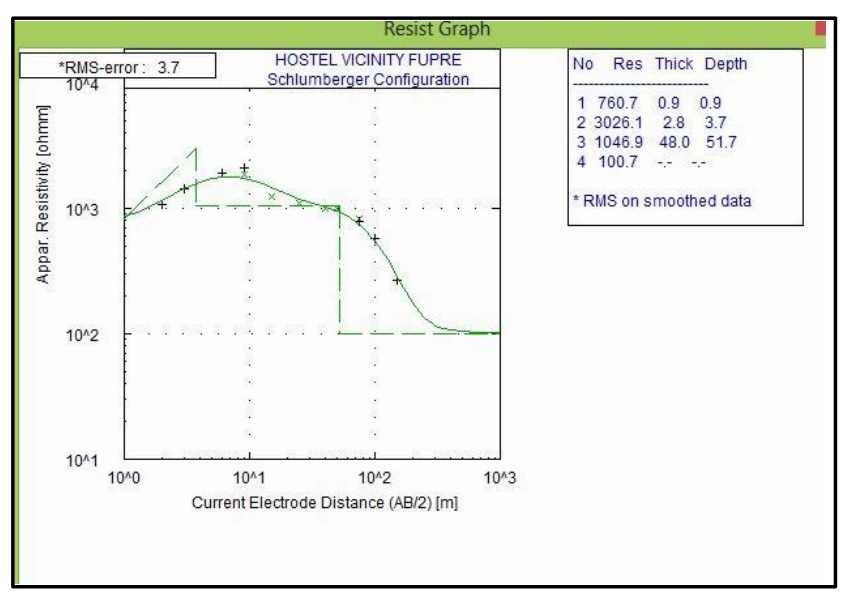

Figure 7: Geoelectric section for VES 5 


\begin{tabular}{|c|c|c|c|c|c|c|c|c|c|c|c|c|}
\hline & & \multirow{4}{*}{$\begin{array}{l}\text { GEOELECTRI } \\
\text { C FACTOR, } \mathrm{K}\end{array}$} & \multirow{2}{*}{\multicolumn{10}{|c|}{ TRAVERSES }} \\
\hline \multirow{2}{*}{\multicolumn{2}{|c|}{$\begin{array}{l}\text { ELECTRODE } \\
\text { CONFIGURATION }\end{array}$}} & & & & & & & & & & & \\
\hline & & & \multicolumn{2}{|c|}{$\begin{array}{l}\text { VES } 1 \\
\text { Lat. } 05^{\circ} 34 \text { '05.1" N; } \quad \text { Long. } \\
005^{\circ} 50^{\prime} 30.6^{\prime \prime} \text { E; Elevation } 13 \mathrm{~m}\end{array}$} & \multicolumn{2}{|c|}{$\begin{array}{l}\text { VES } 2 \\
\text { Lat. } 05^{\circ} 344^{\prime} 07.7^{\prime \prime} \\
\text { N; } \\
\text { Long. } \\
005^{\circ} 50^{\prime} 35.7^{\prime \prime} \quad \text { E; } \\
\text { Elevation 12m }\end{array}$} & \multicolumn{2}{|c|}{\begin{tabular}{|l|} 
VES 3 \\
Lat. 05³4'04.3" \\
$\mathrm{N}$; Long. \\
$005^{\circ} 50^{\prime} 38.2^{\prime \prime}$ E; \\
Elevation 12m
\end{tabular}} & \multicolumn{2}{|c|}{$\begin{array}{l}\text { VES 4 } \\
\text { Lat. } 05^{\circ} 34^{\prime} 09.1^{\prime \prime} \\
\mathrm{N} ; \quad \text { Long. } \\
005^{\circ} 50^{\prime} 38.6^{\prime \prime} \quad \text { E; } \\
\text { Elevation } 14 \mathrm{~m}\end{array}$} & \multicolumn{2}{|c|}{$\begin{array}{l}\text { VES 5 } \\
\text { Lat. 05³4'22.2" N; } \\
\text { Long. } \\
0^{\circ} 5^{\circ} 50^{\prime} 35.2^{\prime \prime} \\
\text { Elevation } 11 \mathrm{~m}\end{array}$} \\
\hline $\begin{array}{l}\mathrm{AB} / 2 \\
\text { (m) }\end{array}$ & $\begin{array}{l}\text { MN/2 } \\
(\mathrm{m})\end{array}$ & & $\mathrm{R}(\Omega)$ & $\rho_{a}(\Omega \mathrm{m})$ & $\mathrm{R}(\Omega)$ & \begin{tabular}{|l}
$\rho_{a}(\Omega \mathrm{m}$ \\
${ }^{\prime}$
\end{tabular} & $\mathrm{R}(\Omega)$ & $\rho_{a}(\Omega \mathrm{m}$ & $\mathrm{R}(\Omega)$ & $\rho_{a}(\Omega \mathrm{m}$ & $\mathrm{R}(\Omega)$ & $\rho_{a}(\Omega \mathrm{m}$ \\
\hline 2 & 0.5 & 11.78 & 68.09 & 802.1 & 46.87 & 552.129 & 109.6 & 1291.1 & 116.7 & 1374.7 & 90.62 & 1067.5 \\
\hline 3 & 0.5 & 27.5 & 37.51 & 1031.53 & 24.64 & 677.6 & 60.24 & 1656.6 & 55.01 & $\begin{array}{l}1512.8 \\
\end{array}$ & 52.2 & 1435.5 \\
\hline 6 & 0.5 & 112.36 & 12.77 & 1434.84 & 6.758 & 759.329 & \begin{tabular}{|l|}
18.7 \\
\end{tabular} & 2101.1 & 18.2 & 2045 & 17.09 & 1920.2 \\
\hline 9 & 0.5 & 253.79 & 6.143 & 1559.03 & 2.72 & 690.309 & \begin{tabular}{|l|l|}
8.327 \\
\end{tabular} & 2113.3 & 7.667 & 1945.8 & 8.358 & 2121.2 \\
\hline 9 & 2 & 60.5 & 28.36 & 1715.78 & 13.47 & 814.935 & 35.3 & 2135.7 & 30.37 & 1837.4 & 31.07 & 1879.7 \\
\hline 15 & 2 & 173.64 & 11.67 & 2026.38 & 4.854 & 842.849 & 8.987 & 1560.5 & 8.966 & 1556.9 & 7.231 & 1255.6 \\
\hline 25 & 2 & 487.93 & 3.980 & 1941.96 & 2.102 & 1025.63 & 2.741 & 1337.4 & 2.538 & 1238.4 & 2.264 & 1104.7 \\
\hline 40 & 2 & 1250 & 1.350 & 1687.5 & 0.8845 & 1105.63 & $\begin{array}{l}0.936 \\
2\end{array}$ & 1170.3 & 0.8256 & 1032 & 0.8083 & 1010.4 \\
\hline 50 & 2 & 1961.14 & 0.787 & 1543.42 & 0.53 & 1039.4 & 0.53 & 1039.4 & 0.4884 & 957.82 & 0.505 & 990.38 \\
\hline 75 & 2 & 4416.5 & 0.251 & 1108.54 & 0.1878 & 829.419 & \begin{tabular}{|l|}
0.178 \\
7
\end{tabular} & 789.23 & 0.1604 & 708.41 & 0.1878 & 829.42 \\
\hline 75 & 10 & 868.21 & 1.167 & 1013.2 & $\begin{array}{l}1.117 \\
\end{array}$ & 969.791 & \begin{tabular}{l|}
0.961 \\
6 \\
\end{tabular} & 834.87 & 0.7839 & 680.59 & 0.9068 & 787.29 \\
\hline 100 & 10 & 1555.71 & 0.451 & 701.625 & 0.4285 & 666.622 & \begin{tabular}{|l|}
0.431 \\
5
\end{tabular} & 671.29 & 0.3401 & 529.1 & 0.3747 & 582.92 \\
\hline 150 & 10 & 3520 & 0.2152 & 757.504 & $\begin{array}{l}0.0746 \\
2\end{array}$ & 262.662 & \begin{tabular}{|l|}
0.109 \\
6 \\
\end{tabular} & 385.79 & $\begin{array}{l}0.0794 \\
1\end{array}$ & 279.52 & $\begin{array}{l}0.0759 \\
9 \\
\end{array}$ & 267.50 \\
\hline
\end{tabular}

Table 2 is a summary of the interpretation of the results of the Vertical Electrical Sounding in the study area. The results show that the area is characterized by four geoelectric subsurface layers. Figure 8 shows the lithologic cross-section for the study area as deduced from the inferred lithology in Table 2.

\begin{tabular}{|c|c|c|c|c|c|c|}
\hline Sounding Locations & \begin{tabular}{|l} 
Geoelectric \\
Layers
\end{tabular} & $\begin{array}{l}\text { Resistivity, } \\
\rho(\Omega \mathrm{m})\end{array}$ & \begin{tabular}{|l} 
Thickness, \\
h(m)
\end{tabular} & \begin{tabular}{|l} 
Depth, \\
D(m)
\end{tabular} & \begin{tabular}{|l|l} 
Inferred \\
Lithology
\end{tabular} & Curve Type \\
\hline \multirow{4}{*}{ VES 1} & $I$ & 668.5 & 1.5 & 1.5 & Clayey Topsoil & \multirow[t]{4}{*}{$\mathrm{AQ}$} \\
\hline & II & 2601.9 & 17.7 & 19.3 & Coarse-grained sand & \\
\hline & III & 634.4 & 27.2 & 46.4 & Clayey sand & \\
\hline & IV & 647.3 & - & - & Clayey sand & \\
\hline \multirow{4}{*}{ VES 2} & I & 573.1 & 3.1 & 3.1 & Clayey Topsoil & \multirow[t]{4}{*}{ KQ } \\
\hline & II & 1155.3 & 20.4 & 23.4 & Medium-grained sand & \\
\hline & III & 1631.2 & 19.1 & 42.6 & Coarse-grained sand & \\
\hline & IV & 74.1 & & - & Wet clay & \\
\hline \multirow{4}{*}{ VES 3} & I & 1065.6 & 1.0 & 1.0 & Silty Topsoil & \multirow[t]{4}{*}{$\mathrm{KQ}$} \\
\hline & II & 2520.2 & 5.2 & 6.2 & Coarse-grained sand & \\
\hline & III & 1102.7 & 43.5 & 49.8 & Medium-grained sand & \\
\hline & IV & 221.9 & - & - & Clay & \\
\hline \multirow{4}{*}{ VES 4} & II & 1231.0 & 1.3 & 1.3 & Silty Topsoil & \multirow[t]{4}{*}{$\mathrm{KQ}$} \\
\hline & II & 2362.5 & 4.7 & 6.0 & Coarse-grained sand & \\
\hline & III & 1106.2 & 34.1 & 40.1 & Medium-grained sand & \\
\hline & IV & 209.9 & - & - & Clay & \\
\hline \multirow{4}{*}{ VES 5} & $I$ & 760.7 & 0.9 & 0.9 & Clayey Topsoil & \multirow[t]{4}{*}{$\mathrm{KQ}$} \\
\hline & II & 3026.1 & 2.8 & 3.7 & Coarse-grained sand & \\
\hline & III & 1046.9 & 48.0 & 51.7 & Medium-grained sand & \\
\hline & IV & 100.7 & - & - & Clay & \\
\hline
\end{tabular}

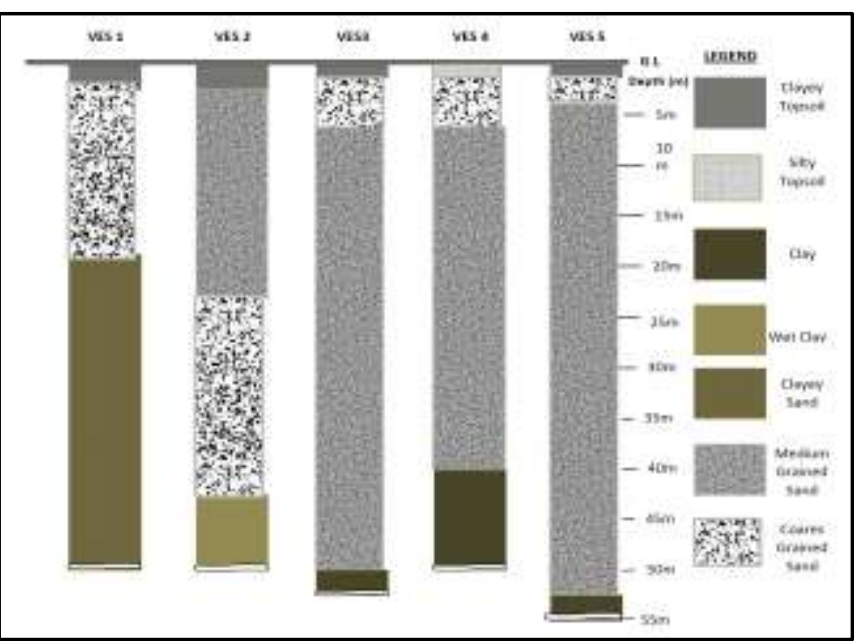

Figure 8: Lithologic cross section for the area
5.2 Discussion

VES 1: Four geoelectric layers of $A Q$ curve type are delineated at this location. Inferred lithologies are characterized by a $1.5 \mathrm{~m}$ thick topsoil that is composed of clayey sand with resistivity of $668.5 \Omega \mathrm{m}$ to a depth of $1.5 \mathrm{~m}$. Below this formation is a $17.7 \mathrm{~m}$ thick coarse-grained sand to a depth of $19.3 \mathrm{~m}$. This is a shallow aquifer zone with resistivity value of $2601.9 \Omega \mathrm{m}$. This is followed by two layers of clayey sand formations with resistivity values of $634.4 \Omega \mathrm{m}$ and $647.3 \Omega \mathrm{m}$ respectively with undetermined thicknesses and depths since they make up the last layers.

VES 2: Four geoelectric layers of KQ curve type are delineated at this location. The $3.1 \mathrm{~m}$ thick topmost sediment to a depth of $3.1 \mathrm{~m}$ is characterized by clayey topsoil materials with resistivity of $573.1 \Omega \mathrm{m}$. Underlying this layer are a $20.4 \mathrm{~m}$ thick medium-grained sand to a depth of $23.4 \mathrm{~m}$ with resistivity of $1155.3 \Omega \mathrm{m}$ and a $19.1 \mathrm{~m}$ thick coarse-grained sand to a depth of $42.6 \mathrm{~m}$ with resistivity of $1631.2 \Omega \mathrm{m}$. The third layer constitutes the deep aquifer zone. Below this zone is a layer of wet clay with resistivity of $74.1 \Omega \mathrm{m}$ and undetermined thickness and depth.

VES 3: Four geoelectric layers of KQ curve type are delineated at this location. Soil layers here are characterized by a porous and permeable $1.0 \mathrm{~m}$ thick silty topsoil with resistivity of $1065.6 \Omega \mathrm{m}$ and depth of $1.0 \mathrm{~m}$. 
Below this layer is a $4.7 \mathrm{~m}$ thick coarse-grained sand to a depth of $6.0 \mathrm{~m}$. This is a shallow aquifer zone with resistivity value of $2520.2 \Omega \mathrm{m}$. However, this is followed by a $43.5 \mathrm{~m}$ thick aquiferous medium-grained sand formation with resistivity values of $1102.7 \Omega \mathrm{m}$ to a depth of $49.8 \mathrm{~m}$. Below this zone is a layer of clay with resistivity of $221.9 \Omega \mathrm{m}$ and undetermined thickness and depth.

VES 4: Four geoelectric layers of KQ curve type are delineated at this location. Similar to VES 3, lithologies here are also characterized by a porous and permeable $1.3 \mathrm{~m}$ thick silty topsoil with resistivity of 1231.0 $\Omega \mathrm{m}$ to a depth of $1.3 \mathrm{~m}$. Underlying this layer is a $5.2 \mathrm{~m}$ thick coarse-grained sand to a depth of $6.2 \mathrm{~m}$. This is a shallow aquifer zone with resistivity value of $2362.5 \Omega \mathrm{m}$. However, this is followed by a $34.1 \mathrm{~m}$ thick aquiferous medium-grained sand formation with resistivity value of $1106.2 \Omega \mathrm{m}$ to a depth of $40.1 \mathrm{~m}$. Beneath this zone is a layer of clay with resistivity of $209.9 \Omega \mathrm{m}$ and undetermined thickness and depth.

VES 5: Four geoelectric layers of KQ curve type are delineated at this location. The $0.9 \mathrm{~m}$ thick uppermost layer to a depth of $0.9 \mathrm{~m}$ is characterized by clayey topsoil materials with resistivity of $760.7 \Omega \mathrm{m}$. Underlying this layer are a $2.8 \mathrm{~m}$ thick coarse-grained sand to a depth of $3.7 \mathrm{~m}$ with resistivity of $3026.1 \Omega \mathrm{m}$ and a $48.0 \mathrm{~m}$ thick medium-grained sand to a depth of $51.7 \mathrm{~m}$ with resistivity of $1046.9 \Omega \mathrm{m}$. The second layer constitutes the shallow aquifer zone. Below the third layer is a layer of clay with resistivity of $100.7 \Omega \mathrm{m}$ and undetermined thickness and depth.

\section{CONCLUSION}

The study reveals that the aquifer characteristics (depth, thickness, resistivity and lithology) vary laterally and vertically from one VES location to another around the students' hostels in FUPRE. This may be due to the difference in mineralogical compositions of the rock types that make up the soil. This non-uniformity in aquifer characteristics implies that prolific groundwater will not occur under the same conditions in different parts of FUPRE hence, the need for this study. The low resistivity values obtained are observed to be prevalent in zones with high clay rockforming minerals which bound the aquifer top and bottom while the high resistivities are observed to be dominant in zones with medium-grained and especially coarse-grained sands which constitute the potential aquifer materials.

Two potential groundwater aquifer zones are delineated in the study area. The unconfined shallow aquifer zones found at VES 1, 3, 4 and 5 locations have shallow overburden depth ranging between $3.7-19.3 \mathrm{~m}$ and coarsegrained sand columns with thicknesses ranging between $2.8-17.7 \mathrm{~m}$ and the confined deep aquifer zone found at VES 2 location coinciding with deep overburden layer at a depth of $42.6 \mathrm{~m}$ and coarse-grained sand column with appreciable thickness of $19.1 \mathrm{~m}$.

\section{RECOMMENDATION}

Sequel to the findings of this study, it is recommended that boreholes for sustainable groundwater supply around the Students' Hostels should be drilled and screened at a depth $\geq 40.0 \mathrm{~m}$ at VES 2 location. However, aquifers at VES $1,3,4$ and 5 have potentials for groundwater but are vulnerable to contamination since they are unconfined. Unconfined aquifer zones have higher tendency of allowing the permeation of contaminant fluids into the groundwater such that in any event of contamination such water becomes unsafe for both domestic and industrial uses.

It is also recommended that electrical resistivity and hydrogeological surveys should be conducted at different locations in FUPRE to delineate the appropriate deep aquifer zones before any borehole(s) are drilled for potable groundwater supply to avoid possible contamination.

\section{REFERENCES}

Akpoborie, I.A., Aweto, K.E., Ohwoghere-Asuma, O., 2014. Urbanization and Major Ion Hydrogeochemistry of the Shallow Aquifer at the Effurun - Warri Metropolis, Nigeria. Environment and Pollution. 4(1), $37-46$.

Alaminiokuma, G. I. and Chaanda, M. S. (2020). Groundwater Potential of Mando, Kaduna, Crystalline Basement Complex, Nigeria, Journal of Earth Sciences and Geotechnical Engineering. 10(2), 15-26.

Amadi, A.N., 2009. Aquifer Characteristics and Groundwater Vulnerability in parts of Warri, Delta State, Nigeria. Journal of Science, Technology and Mathematics Education (JOSTMED). 6(I), 108-123.

Atakpo, E.A., 2013. Geoelectric Investigation of Deghele Community in Warri South West L.G.A, Delta State, Nigeria. Journal of Applied Physics. (1), 46-51.

Avbovbo, A.A., 1978. Tertiary lithostratigraphy of Niger Delta: Bull. Amer. Assoc. Pet. Geol.,62, pp. 291-306.

Etu-Efeotor, J.O., Akpokodje, G.E., 1990. Aquifer systems of the Niger Delta. Journal of Mining and Geolog1. 26 (2), 264-266.

Iloeje, N.P., 1981. A new geography of Nigeria (A new revised edition), published in Great Britain by B. Williams Colwes Ltd, London, pp. 85120.

Iserhien-Emekeme, R.E., Ofomola, M.O., Bawallah, M., Anomohanran, O., 2017. Lithological Identification and Underground Water Conditions in Jeddo Using Geophysical and Geochemical Methods. Hydrology. $4(42), 1-15$.

MgboluI, C.C., Obiadi, I., Obiadi, C.M., Okolo, C.M., Irumhe, P.E. 2019. Integrated groundwater potentials studies, aquifer hydraulic characterization and vulnerability investigations of parts of Ndokwa, Niger Delta Basin, Nigeria. Solid Earth Sciences. 4(3), 102-112.

Nwokocha, C., Uko, E.D., Ngah, S.A., 2018. Aquifer Delineation in Omuma Local Government Area of Rivers State, Nigeria Using Vertical Electrical Sounding Techniques. Journal of Applied Physics. 10(2), 65-70.

Weber, K.J., Daukoru, E.M., 1975. Petroleurn Geology of the Niger Delta. 9th World Petroleum Congr. Tokyo, Proc.2, pp. 209-222.

Whiteman, A., 1982. Nigeria: its Petroleum Geology, Resources and Potential. London: Graham and Trotman Publishers, pp. 301-310

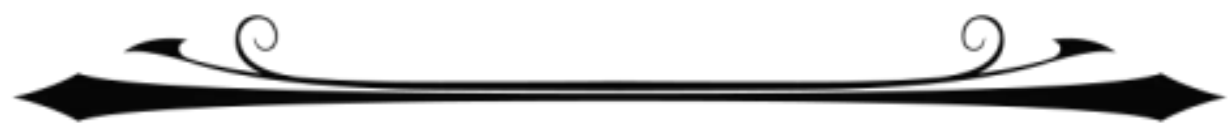

